\title{
Modeling Humanizing Education Through Newly Reviewed Materials Engineering Curriculum
}

\author{
Norshahida Sarifuddin ${ }^{*}$, Zuraida Ahmad ${ }^{1,2}$, Ahmad Zahirani Ahmad Azhar1, \\ Hafizah Hanim Mohd Zaki ${ }^{1}$, Amelia Wong Azman ${ }^{3}$ and Norhuda Hidayah Nordin ${ }^{1}$ \\ ${ }^{1}$ Department. of Materials and Manufacturing Engineering, Kulliyyah of Engineering, \\ International Islamic University Malaysia, Kuala Lumpur, Malaysia \\ ${ }^{2}$ Integrative Engineering Education and Ethics for Sustainability Research Group, \\ Kulliyyah of Engineering, International Islamic University Malaysia, Malaysia \\ ${ }^{3}$ Dept. of Electrical and Electronics Engineering, Kulliyyah of Engineering, \\ International Islamic University Malaysia, Kuala Lumpur, Malaysia. \\ *Corresponding Author: norshahida@iium.edu.my
}

\begin{abstract}
In line with the current global focus on sustainability and the well-being of the planet, becoming a professional engineer nowadays requires more than simple mastery of technical skills. Considering that engineers are required to have a deep sense of responsibility not only for humankind but also for the environment, engineering education and practices must be reformed substantially to prepare engineers that will contribute to sustainable development. This necessitates updating conventional engineering programs (CEE) to incorporate Humanizing Engineering Education (HEE). Although HEE is an old practice of individual engineers and other organizations outside the academic field, it is relatively new in academic engineering. While the definition of what truly merits being considered HEE remains debatable, many engineers believe that their work involves a humanitarian aspect. To streamline the development of HEE, there is a need for developing guidelines and frameworks for a comprehensive model. Ideally, that framework should integrate humanizing pedagogy in the new curriculum design. The objective of the paper is to share the experience of the authors in designing a new curriculum for a Materials Engineering Programme (MEP) that is embedded with Humanitarian Engineering (HE), which is among the main elements of HEE. Data collection was through interviews, qualitative surveys, reports from the stakeholders, accreditation bodies and benchmarking with other Higher Learning Institutions (HLI). An extensive scholarly literature review was executed to identify shortcomings in CEE and how it could be reformed by integrating it with HEE. The Sejahtera Academic Framework (SAF); a strategic framework for academic programmes developed by the university, was used as a reference to customize MEP to better meet students' needs. Since the proposed model applies a new emerging concept, it inevitably raises challenges related to different levels of understanding among course implementers and perceptions of external stakeholders. Moreover, the developers had to consider the limitations imposed by the university's policies and structures while acknowledging the availability of finite resources (i.e. time, money, equipment, and expertise).
\end{abstract}


Keywords: Engineering education, humanising education, Sejahtera Academic Framework, curriculum review

\section{INTRODUCTION}

A career in engineering is very diverse, requiring various and multiple skills. Engineers are required to perform several tasks, including technical supervision, personnel management, development of projects, and diagnostics. Moreover, an engineer must have the ability to communicate across cultures to work with international colleagues and to manage collaborative projects. While engineering education aims to provide persons with all these skills, technical knowledge alone is not sufficient. It is through the humanities, that character development and ethics are incorporated into engineering. That is why there is a need for a renewed focus on Humanizing Engineering Education (HEE).

\section{Humanising Engineering Education (HEE)}

In order to deal with the issue of HEE, it is necessary to understand what is meant by Humanitarian Engineering (HE) practices. Many researchers in Engineering Education (EE) tried to theorize criteria for considering HE which is part and parcel of HEE (Mohammed, 2018; Alam, 2016; Vandersteen, 2018). Vandersteen (2018) depicted four different criteria for differentiating which practices count as HE from conventional practices. To begin with, this work must have a need among the people involved. Second, it should be related to basic human needs. And third, beneficiaries must be involved in the design and implementation of the project. Finally, project implementation should require actual engineering skills and knowledge (Vandersteen, 2018).

Passiono (2015) also proposed a concept which stated that HEE work that meets the most basic human needs, involves marginalized groups, while utilizing a variety of engineering skills and knowledge is "humanitarian engineering." On the other hand, work with less engineering content is called humanitarian work. This concept aids engineers in setting priorities. Engineers specializing in humanitarian engineering, however, need not sacrifice humanitarian values for greater engineering skills. They should first and foremost strive to serve the community.

A larger-scale effort in HE involves different tools and approaches from what is covered in a typical CEE curriculum. Typical CEE curricula are mainly designed to prepare students for employment within the industrial and private sectors, while HE is often conducted within a very different environment. Engineers can make important contributions to the humanitarian and community development sectors if they learn about both technical and non-technical issues, including empathic problem-solving skills. 


\section{MODELLING FOR HUMANISING ENGINEERING EDUCATION (HEE)}

\section{Previous Models of Humanising Engineering Education (HEE)}

Many models have been developed that could be considered to represent HEE. Examples include integrating the humanities, arts and music studies in the engineering curriculum (Kitova, 2018; Zychowska, 2019). However, limited are found for HEE in the context of using engineering knowledge to improve the well-being of societies as proposed by Vandersteen (2018) and Passiono (2015). There are reports on the implementation of HE in the USA (Amadei et al., 2009; Moskal, 2007) in which the HE projects were encouraged to be taken by the students as co-curricular activities. Another model was reported from Australasia (Smith et al., 2017) whereby the students were sponsored for exchange and mobility programmes in least developed countries to undertake humanitarian works. It is important to note that even though many of those models did not use the terms "humanising" or "humanitarian", they had the elements of humanity as viewed from the Islamic perspective in which all are treated equally in gaining human rights and performing duties (Abdelaziz, 2011; Al Mamun et al., 2020; Ahmad et al., 2011). The above frameworks, however, did not explicitly explain how the curriculum was modelled to nurture the students from the beginning, equip them with empathy to understand the problems facing the society, nor use their HE practices to contribute to humanity and solve the problems. Consequently, in this paper, the term HE refers to any work that focuses on solving a basic and crucial human need by using engineering skills and knowledge.

Modelling an engineering curriculum with the embedment of humanitarian engineering practices through the curriculum is going to be unique. Proper considerations need to be taken into account so that it will meet the stakeholders' and the beneficiaries' expectations (e.g., students, accreditation bodies, the community, the Ministry of higher education and sponsors).

There are challenges in these HEE models reported by researchers (Vandersteen, 2018; Passiono, 2015; Kitova, 2018; Zychowska, 2019; Amadei, 2009). Among the main challenges reported by these researchers in executing this HEE were that they require higher student learning time (SLT), the involvement of all beneficiaries, the assessment as well as the ability for the instructors to manage and sustain the activities.

\section{Sejahtera Academic Framework (SAF)}

SAF was developed by the International Islamic University Malaysia (IIUM) to be a strategic framework for humanising the academic programmes in the university (Borhan et al., 2021). The SAF is based on "Maqasid Shariah", comprising of the fundamental need to preserve and protect: Faith, Life, Knowledge, Wealth, and Lineage. Moreover, it incorporates the Falsafah Pendidikan Kebangsaan (National Educational Philosophy) with several other important elements to create a coherent "jami'ah insaniah" (a unique higher education) system. Although students join the university initially to go through an academic programme, the SAF views the entire student experience in addition to the formal curriculum as core elements of molding the students to become holistic human beings leading a harmonious way of life (Insan Sejahtera). This framework is a good template for the programmes to customize their curricula. 


\section{Sustainable Development Goals (SDG)}

When considering the greater scope of HEE curriculum development goals as well as the formal education system's objectives, it is important to note that the prevalent view of the ends of education has always been for the sake of one's livelihood. While the traditional educational system has always prioritized the value system, materialism underlying the knowledge-based economy system and the organizational-based mindset have taken away this primary concern in the modern era. Thus, the concern raised here is that in order to achieve sustainable development, we have to integrate human values in the curriculum. In the context of society's common needs, sustainable development goals (SDG) that derive from worldwide concern and the concern of the whole of humanity are both relevant and engineers can play a great role in their achievement ("UN Sustainable Development Goals", n.d.). The SDGs provide a comprehensive vision and framework that encourages the transformations and balance within the three dimensions of sustainable development (SD); namely, economic, social and environmental. The SDGs framework was set up by the United Nations (UN) in 2015 and is hoped to be achieved by the year 2030. It is important for Higher Education Institutions to adopt the SD agenda and critically help the global community by shaping individuals with collective knowledge, skills, values and attitudes towards sustainable development. By addressing all 17 SDGs, this framework orientates its rationale for the holistic curriculum design that enables the delivery and integration of the elements through education ("UN Sustainable Development Goals", n.d.).

\section{Fourth Industrial Revolution (IR 4.0)}

The Fourth Industrial Revolution (IR 4.0) is expected to change human life, work, and communication media. Compared with prior industrial revolutions, IR 4.0 is producing breakthroughs at a rate unprecedented in history. With their magnitude and depth, these changes herald the reshaping of the entire systems of production, management, and governance (Sahib et al., 2017). Malaysia is not an exception in this transformation which has an impact on the education industry as well, including Engineering, Architecture, Computational designing and Internet of Things (IoT). In modelling the HEE, these IR 4.0 elements need to be taken into account as this advanced technology may in a way be good for HE works.

In line with the IIUM policy of continuous quality improvement and adoption of IR 4.0, as well as UN SDGs, all programmes in the University are required to be reviewed to include the 17 SDGs as part of the Whole Institution Transformation (WIT) approach in their curriculum. 


\section{METHODOLOGY}

The process flow for the development of the HEE for MEP, involves initiating and renewing the plan, analysing the existing curriculum and benchmarking the curriculum from other higher learning institutions, designing the updated curriculum and implementations as shown in Figure 1.

\section{Initiation and Renewal of Plan}

At this stage, the curriculum review (CR) team started the process by planning the curriculum based on: 1) establishing a value base for the program, 2) developing a conceptual framework, 3) determining program goals, 4) design the program, 5) establish programme assessments procedures, 6) implement the programme, and 7) assessing the achievement of the designed curriculum. This paper only reports the process until step four (4) as the implementation is still at the trial stage.

\section{Figure 1}

Process Flow for Reviewing the Curriculum

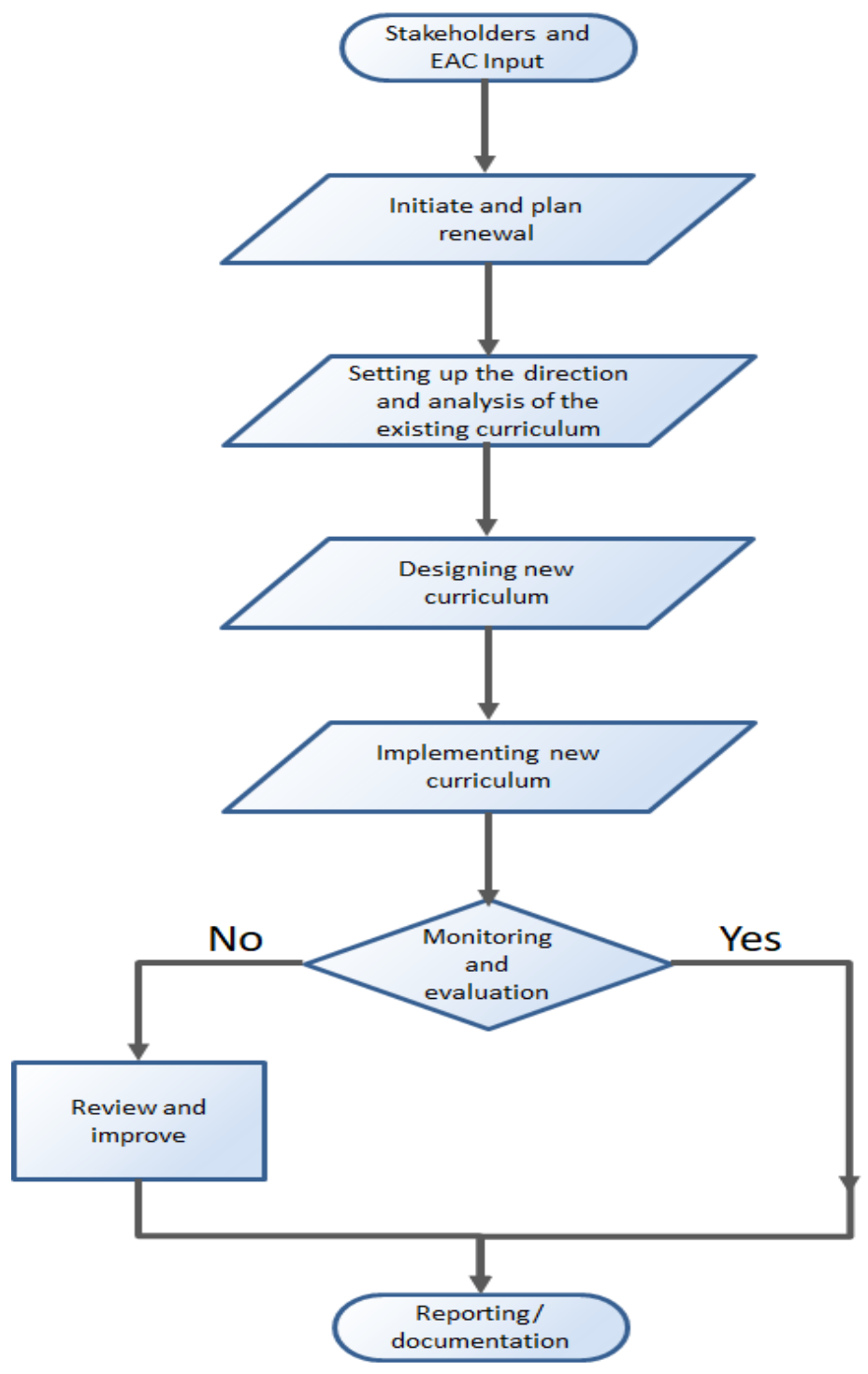




\section{Setting Up the Direction and Analysis of the Existing Curriculum}

\section{Focus Group Discussions (FGD)}

A series of FGDs among the programme's members were conducted to set the direction of the programme and to achieve common understanding on certain terminologies. The state of the level of courses, the standard core courses, the ministry, university and Kulliyyah required courses were also identified. Collected data and information were analysed and structured interviews were also organised to detail out the CQI needed.

\section{Data Collection}

Two types of data were collected for the whole development of CR processes: 1) shortcomings in CEE and 2) models from scholarly literature review and suggestions for HEE. In analysing the existing curriculum, the CR team focused more on the shortcomings of CEE whilst the latter was used in the next stage as a guideline to design a new HEE curriculum. The reports from engineering accreditation councils (EAC), national and international programme evaluators, board of studies (BOS) and Industrial Advisory Panels (IAPs) as well as the semesterly survey from the students were used for this purpose. Benchmarking was also conducted with two institutions namely, University of Malaya and Nanyang Technological University of Singapore (NTU).

\section{Designing New Curriculum for Materials Engineering Programme (MEP)}

Based on the conclusions drawn from the FGDs, the CR team started to develop a conceptual framework, determining the programme outcomes and objectives as well as designing the curriculum.

\section{FINDINGS AND DISCUSSION}

\section{Summary from Focus Group Discussions (FGD)}

The FGD series started with reaching an agreement on certain terminologies. Some of the terminologies were based on the cited literature (Borhan et al., 2021; "UN Sustainable Development Goals", n.d.; Sahib et al., 2017; Arshad-Ayaz et al., 2020; Carew \& Cooper, 2008; Engineering Accreditation Council (EAC), 2020). Table 1 presents the summary of the important terminologies that were discussed. 
Table 1

Summary of the terminologies discussed

\begin{tabular}{|c|c|}
\hline Terminologies Agreed Upon & The Agreed Description \\
\hline Model & $\begin{array}{l}\text { The guidelines (document) used in MEP to determine specific } \\
\text { aspects of teaching, such as subject, time frame, and manner of } \\
\text { instruction. }\end{array}$ \\
\hline $\begin{array}{l}\text { Humanising Engineering } \\
\text { Education }\end{array}$ & $\begin{array}{l}\text { Education with soul, and loaded with values and wisdom. It is } \\
\text { about nurturing a person (hamba Allah) first, a professional } \\
\text { second. (Cited from IIUM road map 2020) }\end{array}$ \\
\hline $\begin{array}{l}\text { Humanising Materials } \\
\text { Engineering Programme }\end{array}$ & $\begin{array}{l}\text { Educate the Materials Engineering students to understand, } \\
\text { internalise and practice Islam in their daily life whilst mastering } \\
\text { the technical courses in MEP }\end{array}$ \\
\hline Nurture & $\begin{array}{l}\text { To continuously educate the students to become good Muslims } \\
\text { and exemplary models in terms of ibadah, akhlaq, knowledge and } \\
\text { professionalism }\end{array}$ \\
\hline Stakeholders & $\begin{array}{l}\text { Students, alumni, staff, community groups, industry and } \\
\text { professions as well as governments are all stakeholders in higher } \\
\text { education }\end{array}$ \\
\hline $\begin{array}{l}\text { Industrial Advisory Panels } \\
\text { (IAP) }\end{array}$ & $\begin{array}{l}\text { Panels from industry appointed by university in certain duration of } \\
\text { time }\end{array}$ \\
\hline Industry people & $\begin{array}{l}\text { People who are working in the industry who are serving and } \\
\text { requiring engineering personnel }\end{array}$ \\
\hline
\end{tabular}

Taking into account the stakeholders' request, and university aspiration translated into SAF (Borhan et al., 2021), humanising education was set as the direction for MEP, and certain elements were discussed to accommodate the values set. The knowledge and skills required are summarised in Table 2. 
Table 2

Summary from Focus Group Discussions (FGD) on direction setting for Materials Engineering Programme (MEP)

\begin{tabular}{|c|c|c|c|}
\hline Direction (Value) & $\begin{array}{l}\text { Humanising } \\
\text { Elements }\end{array}$ & $\begin{array}{l}\text { Knowledge required } \\
\text { (Cognitive and } \\
\text { Affective Domains) }\end{array}$ & $\begin{array}{l}\text { Skills Needed } \\
\text { (Psychomotor) }\end{array}$ \\
\hline $\begin{array}{l}\text { A holistic Materials } \\
\text { Engineering } \\
\text { education model that } \\
\text { nurtures Materials } \\
\text { Engineering } \\
\text { graduates, to be } \\
\text { balanced persons } \\
\text { who lead and } \\
\text { promote good for all } \\
\text { (Humanising } \\
\text { Materials } \\
\text { Engineering } \\
\text { Education) }\end{array}$ & $\begin{array}{l}\text { Endeavors towards a } \\
\text { sustainable } \\
\text { environment by } \\
\text { promoting innovative } \\
\text { green materials and } \\
\text { processes, and } \\
\text { striving for } \\
\text { limitations of } \\
\text { destruction and } \\
\text { corruption } \\
\text { Economical } \\
\text { Materials for the } \\
\text { economic } \\
\text { sustainability of the } \\
\text { nations }\end{array}$ & $\begin{array}{l}\text { Importance of } \\
\text { materials } \\
\text { - Type of materials } \\
\text { and their properties } \\
\text { - Application of } \\
\text { Materials }\end{array}$ & $\begin{array}{l}\text { - } \text { Reflective thinking } \\
\text { - } \text { Creative and } \\
\text { Critical thinking } \\
\text { - Scientific thinking } \\
\text { - Empathy }\end{array}$ \\
\hline
\end{tabular}

The programme is in agreement with the university aspiration to produce balanced students who are religiously good (taqwa) and at the same time become professional engineers leading the world in the Materials Engineering area. This aspiration led to the discussion on the elements necessary to be instilled in the students such as the appreciation of all the things created by the Creator, whereby the materials engineers who are also the Khalifah of Allah (Vicegerents) are given the responsibilities (Amanah) to take care of the worlds through continuous knowledge (Iqra') obtained and to do good and ensure the well-being of the society (Rahmatan Lil 'alamin). The attributes as Khalifah (Kh), Amanah $(A)$, Iqra'(I) and Rahmatan lil 'alamin $(R)$ are the attributes aspired by the university in its KhAIR concepts (Borhan et. al., 2021). The direction of the MEP for the students is to be highly technical, to master the materials engineering fundamentals as well as advanced materials and be equipped with the current technology in line with the global need of Fourth Industrial Revolution (IR 4.0). This is set for the students to become professional Materials Engineering Muslim. 


\section{Data Collection Analysis}

Once the direction was set, data and information based on the feedback from stakeholders, EAC panels, evaluators were analysed for CQI on the previous curriculum and identifying the humanising elements recommended. There was a long list of data and only some of the relevant suggestions for the HEE curriculum were grouped and summarised as in Table 3.

\section{Curriculum Development}

A framework for MEP was developed emphasizing the elements that have been highlighted in the previous sections. The five (5) pillars of education proposed in SAF (Borhan et. al., 2021) on learning to know, learning to do, learning to live together, learning to be and learning to become are used to guide educators' actions in order to make learning fit the changes experienced from reality. Moreover, they advocate for holistic development of the individuals by providing skills of argument and offering reasoned opinions, instead of merely making decisions without proper and exhaustive logical reasoning as well as gaining the experience necessary to break into the career as Material Engineers.

Table 3

Some suggestions relevant to humanising engineering education

\begin{tabular}{|c|c|c|}
\hline Stakeholders & $\begin{array}{l}\text { Suggestions from panels on improvement } \\
\text { that can be done to the new curriculum }\end{array}$ & Analysis and plan \\
\hline $\begin{array}{l}\text { International } \\
\text { External Examiner } \\
\text { (Engineering } \\
\text { Accreditation } \\
\text { Council (EAC), } \\
\text { 2020) }\end{array}$ & $\begin{array}{l}\text { 1. 'Critical thinking' could be identified as a } \\
\text { part of PO2 (Problem analysis) since it } \\
\text { would be fruitful to apply this approach } \\
\text { from the first stage of investigating a } \\
\text { problem. } \\
\text { 2. Modelling, simulation and programming } \\
\text { throughout the courses is very forward } \\
\text { looking. It is encouraged to apply them in a } \\
\text { more adventurous scope, and to embed } \\
\text { them in the topics where the students learn } \\
\text { the technical content (rather than as } \\
\text { separate modules), so that this can be } \\
\text { treated as a common activity. }\end{array}$ & $\begin{array}{l}\text { Being professional Muslim } \\
\text { engineers, critical thinking and } \\
\text { simulation skills are a must and } \\
\text { added advantages. It is planned that } \\
\text { the skills must be embedded and } \\
\text { implemented in the courses as early } \\
\text { as possible and also throughout the } \\
\text { studies. }\end{array}$ \\
\hline \multirow[t]{2}{*}{$\begin{array}{l}\text { External Assessor } \\
\text { Report (Engineering } \\
\text { Accreditation } \\
\text { Council (EAC), } \\
\text { 2020) }\end{array}$} & $\begin{array}{l}\text { 1. The arrangement of the courses in the } \\
\text { curriculum can be slightly modified to } \\
\text { ensure the students gain certain knowledge } \\
\text { before proceeding with other tough } \\
\text { subjects. }\end{array}$ & $\begin{array}{l}\text { A concrete foundation in materials } \\
\text { is needed so that the students are } \\
\text { able to grasp the study of higher } \\
\text { levels of materials engineering. }\end{array}$ \\
\hline & $\begin{array}{l}\text { 2. The problem-based topics from various } \\
\text { types of industry should be considered in } \\
\text { the integrated design project course. } \\
\text { Perhaps direct involvement from the } \\
\text { industrial advisory panel in providing } \\
\text { topics based on problems faced by their } \\
\text { industries can be considered. }\end{array}$ & $\begin{array}{l}\text { To produce holistic students who } \\
\text { can serve the society (ummah). } \\
\text { Experiential learning by solving real } \\
\text { industry problems is a good } \\
\text { platform for the students and } \\
\text { involvement of IAP will be a great } \\
\text { advantage. }\end{array}$ \\
\hline
\end{tabular}


Table 3 (continued)

\begin{tabular}{|c|c|c|}
\hline Stakeholders & $\begin{array}{l}\text { Suggestions from panels on improvement } \\
\text { that can be done to the new curriculum }\end{array}$ & Analysis and plan \\
\hline Industry & $\begin{array}{l}\text { Propose to include more soft skills related } \\
\text { to the curriculum as well such as technical } \\
\text { presentations skills, technical writing } \\
\text { skills, communications skills and maybe } \\
\text { programming skills (such as Arduino, R, } \\
\text { Python etc). Need to include the latest } \\
\text { programming language such as R, Python } \\
\text { etc. }\end{array}$ & $\begin{array}{l}\text { Communication skills in writing, } \\
\text { presentation, interdisciplinary and } \\
\text { intercultural social interactions are very } \\
\text { much needed for the materials engineering } \\
\text { graduates to deliver their projects. Such } \\
\text { skills will also be helpful when persuading } \\
\text { and influencing the society to working } \\
\text { together with them and choosing } \\
\text { alternative materials and processes to } \\
\text { safeguard the environment for Rahmatan } \\
\text { lil alamin. }\end{array}$ \\
\hline Alumni & $\begin{array}{l}\text { Current engineering graduates entering the } \\
\text { workforce are expected to be well versed in } \\
\text { using software for gathering and analyzing } \\
\text { data. It is observed that the syllabus change } \\
\text { is heading towards the same direction. } \\
\text { Coding also needs to be introduced. }\end{array}$ & $\begin{array}{l}\text { To be able to serve the society and industry } \\
\text { in the era of IR } 4.0 \text {, the programmes must } \\
\text { be well versed in using latest automation } \\
\text { software and technology that are related to } \\
\text { materials engineering. }\end{array}$ \\
\hline $\begin{array}{l}\text { Benchmarking } \\
\text { Report (NTU } \\
\text { and UM) }\end{array}$ & $\begin{array}{l}\text { The elements of sustainability, in relation } \\
\text { to SDGs, are embedded into three ( } 3 \text { ) } \\
\text { General Education Courses (GER) in NTU } \\
\text { and general requirements in UM. }\end{array}$ & $\begin{array}{l}\text { To nurture the students to implement the } \\
\text { concept of Khalifah, they need to be aware } \\
\text { of the global scenarios on poverty and how } \\
\text { they can play their role as Materials } \\
\text { engineers. Elements of sustainability } \\
\text { should be embedded in certain subjects } \\
\text { while the pillars of Learning can be focused } \\
\text { in stand-alone subjects prepared by the } \\
\text { university. }\end{array}$ \\
\hline $\begin{array}{l}\text { EAC Report } \\
2018\end{array}$ & $\begin{array}{l}\text { Open-ended type Laboratory Manual does } \\
\text { not truly demonstrate the spirit of } \\
\text { 'guidance free' laboratory work, which will } \\
\text { expose students to analytical skills and } \\
\text { prepare them for their Final Year Project, } \\
\text { especially those which are } \\
\text { research/experimental based. }\end{array}$ & $\begin{array}{l}\text { Engineer is in need of analytical skills not } \\
\text { just for technical decisions but also for } \\
\text { ethical decisions in the workplace. } \\
\text { Therefore, these will be embedded in MEP. }\end{array}$ \\
\hline
\end{tabular}

Learning in this newly designed MEP leads to students having a better understanding of the material world around them, openness to knowing both their own world and the world of others, and protecting them from ignorance. As they practice and absorb the knowledge, they move away from immobility. They learn to live together, develop a sense of teamwork, and avoid isolation. In learning to become they are modelled on Muslim engineers who exhibit expertise and are contributing to the ummah by helping solidify and harmonize the pillars of the religion and the human person. 
Learning to know requires the acquisition and development of knowledge and skills necessary to function in society. Fundamental knowledge in materials engineering and critical thinking are among the two things needed in this pillar. At this stage only cognitive learning domain is required. Learning to do, involves cognitive and some psychomotor abilities. It requires the skills that enable the materials engineering students to effectively participate in the classroom setting and in global society. It is decided that the skills and competencies under this pillar are linked to technical skills, leadership and management competencies. On the other hand, Learning to live together requires abilities such as cognitive, affective and psychomotor. It also involves the development of social skills and values such as respect and concerns for others, social and interpersonal skills and an understanding of the breadth of human experience. In this pillar the $\mathrm{CR}$ team is proposing courses with its instructional strategies of being in a team and problem-solving activities in the classroom setting. Students learn to be holistically developed (body, mind, and spirit) in Learning to Be, cultivating the qualities of an all-around 'complete person.' These include cultivating students' analytical and social skills, creativity, personal discovery and an appreciation of the inherent value provided by these pursuits. Industrial and societal problem-based projects are expected to be part of this pillar, which will be executed in groups. Finally, Learning to become, takes into account the harmonising and integrating the whole studies into a cycle and provides a platform for continuous building of skills and knowledge throughout the life of the students.

Our design of the model for MEP is based on these five pillars of education. The MEP curriculum starts students' learning journey by developing students' empathy for their surroundings. This will enable them to identify and define societal problems related to the technology know-how and ideation or finding reasonable solutions to the problems before design comes into the picture. Soon after, prototyping and testing based on the ideas will follow suit. The knowledge learned and the project designed then will be delivered back to the society through the University Social Responsibility or Technopreneurship course. This framework is adapted from the IIUM SAF framework. The courses in the programme will be reviewed, designed and distributed to align with the framework as shown in Figure 2. Detail explanations of the courses are given in Table 4.

The CR team has decided to maintain the programme outcomes and programme objectives previously established as they are almost in line with the HEE model that is going to be developed. The 12 POs keywords are: PO1- Engineering knowledge; PO2 - Problem Analysis (T); PO3- Design/Development of Solutions; PO4-Investigation, PO5-Modern Tool, PO6Engineering and society; PO7 - Environment and sustainability; PO8-Ethics; PO-9; Individual and team works, PO10-Communication, PO11- Project Management and Finance, PO12-Life Long Learning. 


\section{Figure 2}

Customised Framework for Materials Engineering Programme

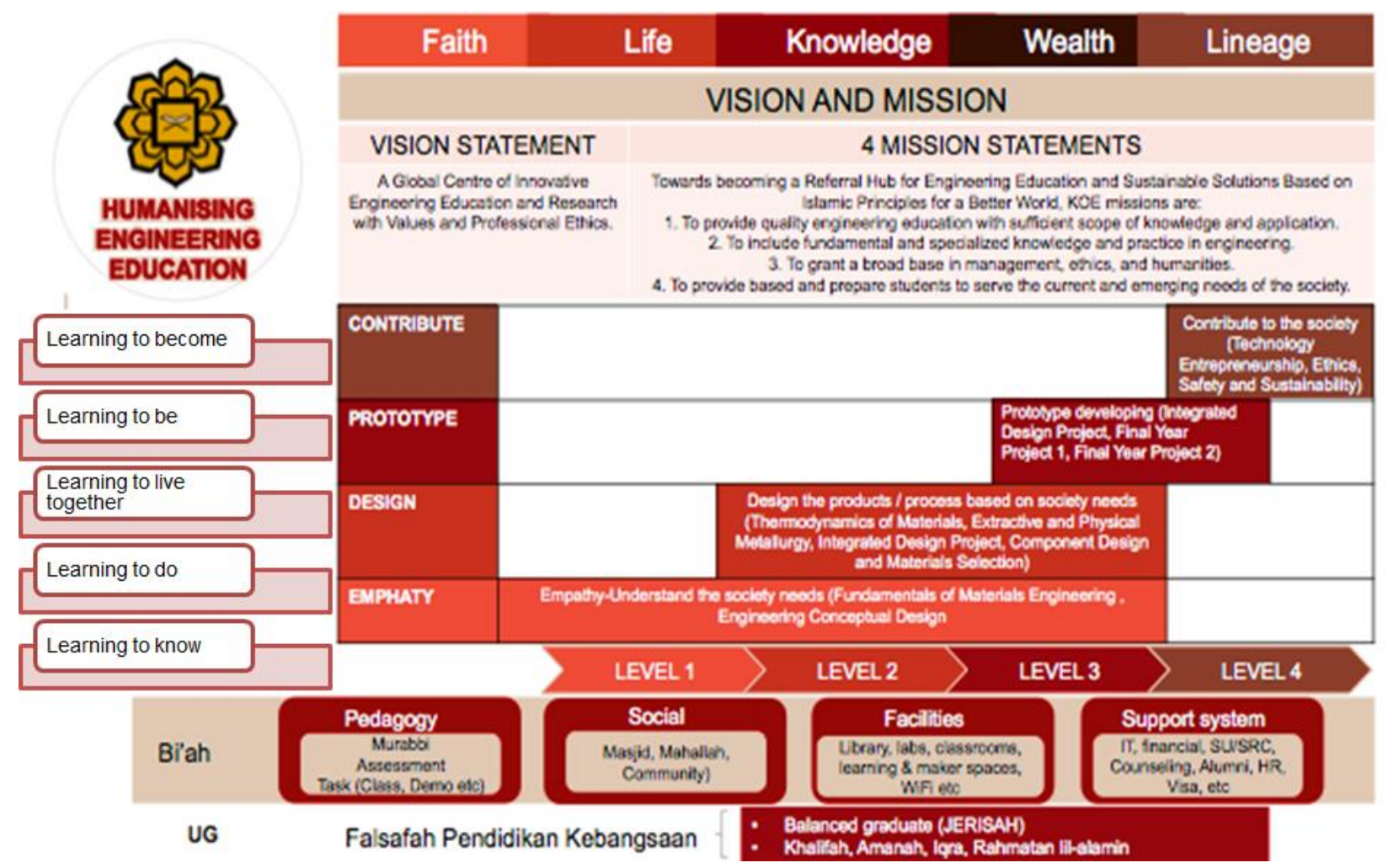

Table 4

Programme Core Courses with Elements of MS/SAF/FPK/IIUM Vision and Mission required by the University (Humanising Engineering Education/Rahmatan lil'Alamin)

\section{Elements of} $\mathrm{MS} / \mathrm{SAF} / \mathrm{FPK} /$ contribution to society

Empathy Understand the society needs

Design the products/process based on the society needs

Prototyping and Performance Evaluation Contribute to the society through the designed product/process $\begin{array}{ll}\text { Course } & \text { POs }\end{array}$

Fundamentals of Materials Engineering $\quad$ PO1, PO2, PO6, PO7

Engineering Conceptual Design

PO3, $\mathrm{PO} 8, \mathrm{PO} 9$

(Taking in parallel with Usrah in Action 1 course)

Thermodynamics of Materials

Extractive and Physical Metallurgy

Integrated Design Project

Component Design and Materials

Selection

$\mathrm{PO} 1, \mathrm{PO} 3, \mathrm{PO} 7, \mathrm{PO} 12$

$\mathrm{PO} 1, \mathrm{PO} 2, \mathrm{PO} 6, \mathrm{PO} 7$

$\mathrm{PO} 3, \mathrm{PO} 7, \mathrm{PO} 9, \mathrm{PO} 10$

$\mathrm{PO} 1, \mathrm{PO} 3, \mathrm{PO} 5$

$\mathrm{PO} 2, \mathrm{PO} 3, \mathrm{PO} 7, \mathrm{PO} 9, \mathrm{PO} 10$

$\mathrm{PO} 1, \mathrm{PO} 2, \mathrm{PO} 4, \mathrm{PO} 10$

$\mathrm{PO} 1, \mathrm{PO} 2, \mathrm{PO} 4, \mathrm{PO} 10, \mathrm{PO} 12$

PO11

(parallel with Usrah in Action 2 course)

Ethics, Safety and Sustainability

PO6, PO7, PO8, PO9 
The IR4.0 and UN SDGs are relevant to humanising engineering education as they are expected to change human life, work, and communication media. Therefore, the Materials Engineering program has also taken into consideration these two elements which aims to produce an 'Insan Sejahtera' who is well versed in all aspects and turns it into a world class Materials Engineering curriculum. Therefore, the mapping of the subjects to these components is presented in Table 5.

Table 5

Courses with Elements of IR 4.0/IoT and SDG required by the University

\begin{tabular}{|c|c|c|}
\hline IR 4.0/IoT Areas & Course & SDG \\
\hline \multirow{9}{*}{ Simulation } & CAD and Simulation & 9 \\
\hline & Materials Fluid Dynamics & 7,9 \\
\hline & Heat and Mass Transfer & 7 \\
\hline & Materials Characterization and Non Destructive Testing & 7 \\
\hline & Heat Treatment and Microstructure Control & 9 \\
\hline & Materials Engineering Lab 1 & 9 \\
\hline & Materials Engineering Lab 2 & 9 \\
\hline & Materials Engineering Lab 3 & 9 \\
\hline & Ceramics & 12 \\
\hline \multirow{4}{*}{$\begin{array}{c}\text { Additive } \\
\text { Manufacturing }\end{array}$} & Polymers & 9 \\
\hline & Materials Processing Technology & 9 \\
\hline & Powder Metallurgy & 9 \\
\hline & Materials Engineering Lab 4 & 9 \\
\hline IoT & Instrumentation and Control System & 9 \\
\hline \multirow{7}{*}{$\begin{array}{l}\text { Sustainability / } \\
\text { Environment }\end{array}$} & Thermodynamics of Materials & 7,12 \\
\hline & Extractive and Physical Metallurgy & 9,12 \\
\hline & Composite & 9 \\
\hline & Waste Materials Processing & 7,9 \\
\hline & Corrosion & 9 \\
\hline & Polymer & 12 \\
\hline & Failure Analysis of Materials & 9 \\
\hline \multirow{5}{*}{$\begin{array}{l}\text { Advanced } \\
\text { Materials }\end{array}$} & Semiconductors & 7,9 \\
\hline & Surface Engineering and Tribology & 12 \\
\hline & Nanomaterials & 9 \\
\hline & Smart Materials & 3,9 \\
\hline & Electroceramics & 12 \\
\hline
\end{tabular}

In this paper, the process and explanation to obtain HEE are not explicitly mentioned. It is also apparent that the methods and tools described are not comprehensive in their approach to reviewing the engineering education curriculum. Nevertheless, these processes and tools are being tested and adapted in real-time in order to support the curriculum reviews of the Materials Engineering programme that the authors have been involved with. Since the curriculum review exercise can be challenging, engineering communities or academicians are required to put 
together collective capabilities, knowledge, and resources to support this important endeavor. As described above, the ideas and processes appear to have assisted the academician in making sense of the materials engineering curriculum that is complex and in making decisions to change it collectively.

\section{Expected Challenges in Implementing the Revised Curriculum}

As discussed, there are many challenges faced by the educators in HEE (Vandersteen, 2018; Passiono, 2015; Kitova, 2018; Zychowska, 2019; Amadei, 2009). With this newly developed society-based curriculum for HEE, the approach taken might be a bit different from the existing curriculum. This requires the academicians to sit together and brainstorm the right strategy and approach. The inter-related activities between one course and another call for the course owners to understand how some parts of their courses are related to the others. The stake-holders also need to be briefed about the new curriculum so that they will have appropriate perception of it. The academicians need to maintain their good understanding and clear view on all the constraints of the policies and structures of the university, the financial sufficiency, and availability of the appropriate equipment for teaching and learning. In addition, the academicians also need to consider the skills and expertise needed to execute this complex activity as well as the time and duration involved in implementing society-based curriculum that requires students to be engaged with the society on-site. 


\section{CONCLUSION}

In fulfilling the aspiration of university, MEP in Kulliyyah of Engineering, IIUM, has revamped its curriculum in the recent curriculum review, with the intention to produce a holistic Materials Engineering education model that nurtures materials engineering graduates to be balanced persons who can lead the way and promote good for all. The humanising elements proposed in the model include appreciation of the materials created by the Creator, endeavoring to create a sustainable environment by promoting innovative green materials and processes, and striving towards eliminating destruction and corruption. These can be achieved through the five pillars of education: learning to know, learning to do, learning to live together, learning to be and learning to become; while promoting the concepts of KhAIR (as a leader (khalifah) of Allah, taking the responsibility (Amanah) to protect this world as a materials engineer, and using knowledge (Iqra') in materials engineering for the well-being of the society (Rahmatan lil 'Alamin).

\section{ACKNOWLEDGEMENT}

The authors would like to acknowledge the efforts and contribution by the former curriculum review leader the late Prof Dr Iskandar Idris Yaacob for initiating and stimulating the idea to come up with practical and good society-based materials engineering curriculum. We also acknowledge the contributions from all academicians of the Materials Engineering Programme, all heads of Program Accreditation and Quality Assurance (PAQA) of the KoE, Staff of KoE and Office of Knowledge for Change and Advancement (KCA). 


\section{REFERENCES}

Abdelaziz, B. (2011). Islamisation in modern sciences: the way forward. Revelation and Science, 1 (3), 21-34. ISSN 2229-9947

Ahmad, Z., Ismail, A. F., Shafie, A. A., Ihsan, S. I., Halim, Z. and Albat'hi, S. A. M. (2011). Islamisation of Engineering Education in International Islamic University Malaysia (IIUM): Problems and Prospect, Revelation and Science, 1 (3), 131-137.

Al Mamun, A., Muthalif, A. G. A., Ahmad, Z., Ismail, A. F., Ismail, K., and Abdul Maleque, M. (2020). Islamisation of Engineering Education - A Case at IIUM. Universal Journal of Educational Research, 8(2), 355 - 361. DOI: 10.13189/ujer.2020.080204

Alam, N.A.R. (2016). Application of Humanistic Values in Islamic Education; The Challenges Of Human Potentials in Modern Era, June 2016, Ta allum Jurnal Pendidikan Islam, 4(01), 173-192. https://doi.org.10.21274/taalum.2016.4.01.173-192

Amadei, B., Sandekian, R. \& Thomas, E. (2009). A Model for Sustainable Humanitarian Engineering Projects. Sustainability, 1(4), 1087-1105. https://doi.org/10.3390/su1041087

Arshad-Ayaz, A., Naseem, M. A., and Mohamad, D. (2020). Engineering and humanitarian intervention: learning from failure. Journal of International Humanitarian Action, $5,7$. https://doi.org/10.1186/s41018-020-00073-5

Borhan, L., Azman, A. W., Mat Ghani, G., Abdullah, M. F., Abdul Rahman, Z., and Yusoff, Z. M. (2021). Sejahtera Academic Framework: Humanising education for Rahmatan lilAlamin post-COVID-19 disruption. International Islamic University Malaysia. ISBN 978-967-467-018-4.

Carew, A. L., and Cooper, P. (2008). Engineering curriculum review: processes, frameworks and tools. Conference of the European Society for Engineering Education, 1007-1016. Aalborg, Denmark: SEFI.

Engineering Accreditation Council (EAC) (2020). Engineering Programme Accreditation Standard 2020 (Manual).

Kitova E.T. (2018). Humanization and Humanitarization of Engineering Education. In: Filchenko A., Anikina Z. (eds) Linguistic and Cultural Studies: Traditions and Innovations. LKTI 2017. Advances in Intelligent Systems and Computing, vol 677. Springer, Cham. https://doi.org/10.1007/978-3-319-67843-6_8

Mohammed, B. (2018). Humanizing Engineering Education: A Comprehensive Model for Fostering Humanitarian Engineering Education. International Journal of Modern Educational Studies, 2(1), ISSN 2618-6209

Moskal B., Gosink J. (2007) Humanitarian Engineering Curriculum: Defining Student Learning Outcomes, American Society for Engineering Education, 12.815.1-7.

Passiono, K. (2015). Humanitarian Engineering Creating Technologies that Help People (2nd ed.). Columbus, Ohio: Library of Congress. 
Sahib, S., Ithnin F., and Mohd Isa, K. R. (2017). Future of Malaysia Technical University Network (mTun) In the Light of the 4th Industrial Revolution, Techies, MBOT Official Bulletin 4th Edition.

Smith, J., Anderson, B., Brown, N., Colley, A., Stoakley, A., \& Turner, J. (2017). The Rise of Humanitarian Engineering Education in Australasia. In the 28th Annual Conference of the Australasian Association for Engineering Education (AAEE 2017). Sydney: Australasian Association for Engineering Education, 312-320. https://search.informit.org /doi/10.3316/informit.390763431262433

UN Sustainable Development Goals (n.d.). Retrieved from Wikipedia on 1 September 2021. https://en.wikipedia.org/wiki/Sustainable_Development_Goals

Vandersteen, J.D.J. (2018). Humanitarian Engineering in the Engineering Curriculum. Diss. Queen's U, Canda, n.p., 2008. Print.

Zychowska, M.J. (2019). Humanisation of engineering studies. World Transactions on Engineering and Technology Education, 7(3), 250-253. 